\title{
一過性脳虚血発作の成因
}

\author{
澤田街・水上 公宏* \\ Pathogenesis of Transient Ischemic Attack \\ Tohru Sawada and Masahiro Mizukami* \\ Department of Internal Medicine, Kitasato University \\ * Department of Neurosurgery, Institute of Brain and Blood \\ Vessels, Mihara Memorial Hospital
}

\begin{abstract}
Summary
Pathogenesis and etiologic factors in transient ischemic attack (TIA) were briefly reviewed with emphasis on intra- and extracranial atherosclerotic changes and indication for surgery.

TIA is a clinical syndrome, which can only be defined by clinical features and is not confined to specific pathological changes in the brain or in the vascular system. Various pathogenic concepts and etiologic factors have been reported in the literature. The vasospasm theory in pathogenesis of TIA is now almost abandoned. There have been no experimental findings nor any other grounds to assume that vasospasm frequently causes TIA. Most patients with TIA become symptom-free by anticoagulation and many other evidences suggest that vast majorities of TIA are due to thromboembolism including so-called "microembolism." However, transient fluctuations of cerebral perfusion pressure can also be a causative factor of TIA in a small number of cases, as pointed out by DennyBrown (so-called "cerebrovascular insufficiency"). In either case, the main etiologic factor can be attributed to atherosclerotic changes in the intra- and extracranial arteries. Incidences of vascular changes in the intracranial cerebral arteries seem to be higher in this country than in European countries or in the USA.

In rare cases of TIA, various other pathogenic conditions, such as polycythemia, thrombocytosis, kinkings and coilings of the cervical arteries, subclavian steal syndrome, moyamoya disease, etc, have been reported or experienced.

Thromboendarterectomy of the cervical arteries and superficial temporal artery-to-middle cerebral artery (STA-MCA) anastomosis have been tried for surgical management of TIA. From a pathogenic point of view, thromboendartectomy is recommended for cases of TIA, which is caused by thromboembolism originated from atherosclerotic foci in the cervical arteries, while STA-MCA anastomosis might possibly be applied to cases of cerebrovascular insufficiency due to various vascular changes such as stenosis of the middle cerebral artery, internal carotid occlusion, and moyamoya disease.
\end{abstract}

Key words: transient ischemic attack, cerebrovascular insufficiency, microembolism, thromboendarterecty, STA-MGA anastomosis

一過性媨血発作（transient ischemic attack，以下 TIA と略す）は，譄虚血により局所神経症状が出現するが， 24時間以内に痕跡を残さず完全に回復する症候群の総称 である，脳卒中病型上してはもっとも軽症のものである が，一方では impending strokeともいわれ，より重篤な
卒中発作の前兆として重視されている．本症の発症には 頭蓋内外の媨灌流動脈の病変が密接に関与しており，こ ため血行再建術特に最近では STA-MCA 吻合少の適応 疾患として TIA が重梘されつつある る272。 しかし， TIA は臨床症状によって定義される症候群であって，

北里大学内科（現国立循環器病センター内科）

* 脑血管研究所美原記念病院脸神経外科

〔連絡先： $=565$ 吹田市藤白台5-125, 国立循環器病センタ一内科, 澤田徹〕

1978年1月 6 日 受稿 
特定の脑または血管の器質的変化に対応した疾患ではな い.TIAの臨床像を示すものの中には，種々の病態によ るものが含まれ，その成因も一律ではない(13488，そのた め, TIAの定義そのものにも混乱がある.

今回著者らは TIA の成因について述べる機会を与え られたが，自験例が限られて㧍り，寸べてを明らかにす ることは不可能である．そこで，TIAの臨床的概念につ いて意見を述べるとともに，血行再建術に関連してTIA の発生機序の多様性に触九てみたい。

\section{TIA の概念}

TIAを論ずる場合，まずその臨床的概念もしくは診断 基準を明らかにしておく必要がある。

内外の脳血管障害の分類に括ける TIA の診断基準は 必ずしむ同じではない，我国の標準的分類である文部省 総合研究班のむのでは ${ }^{12}$,「脑硬塞を伴わない一過性腷 虚血」という項目があり，これを反復性局所性嗵虚血発

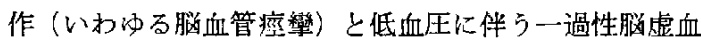
にわけている。 しかし，後者に失神，急性失血，心施硬 塞, Adams-Stokes 症候群，外傷性㧍よび外科的ショッ クなどをで含めている。これは，後述する上うに，脳血 管不全に対する概念の混乱の影響を受けたためと考えら れるが，遒血管障害にショック時の意識障害や単なる失 神発作まで含めるの梳妥当性を欠くと思われる。このた め, TIA在狭義に解釈して, 反復性局所性脳虚血発作に 限定しているものもある ${ }^{13)}$. WHO の分類では ${ }^{25)}$ ，脳梗 塞や頭蓋内出血など病理的变化によって分類される病型 に対比して，臨床症状加分類される脳卒中病型として TIAをあげ，「局所性神経性脱落症状で，普通数分つぶき 24時間を越えず，痕跡を残さず治り，血管病変を有する 患者に起こるもので，しばしば再発する傾向がある。偏

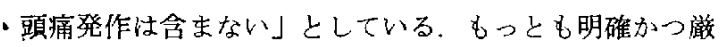
密な規定をしているのは, 米国 Joint committee for stroke facilities の診断基準である ${ }^{20)}$ ，すなわち，起こりうべき 症状を内頸動脈系と椎骨脳底動脈采に分けて詳細に規定 し，失神発作や単なるめまいなどそれ以外の14項目を除 外している。また発現様式の特街としては，(1)局所的な 神経症状である，(2発症が急激（5 分以内）で，進行性 ではない，(3)症状持続が24時間以内，通常数分から 30 分 である，(4)症状寛解が迅速であるなどの諸点を指摘して いる.

著者らは，TIA の最大の特徵はその臨床症状の temporal profile にあると考えるが，出現する症状は局所的 な脳虚血に上る果症状であるべきであると考えている。 ショック時の意識障害まで脳血管障害の一病型と寸るの
は妥当性を欠くと思方れるからである，しかし，TIAの 診断はあくまで臨床症状によって行うべきものであり， 血圧変動によって典型的な反復性局所性媨虚血発作を生 じうる場合もあることから（症例 1 )，微小塞栓によるも ののみを狭義の TIA と寸るといら立場は上らない，加 かる観点からみると，上記米国の診断基淮が現在もっと む妥当であると思わ扎る，したがって，以下の議論耴お ける TIA は，この診断基準に適応するものを指す。

\section{TIA の発症機序}

一過性の脳虚血発作の存在はかなり古くから知られて おり，その発症機序の説明も寸でに前世紀末に試みられ ている ${ }^{22411}$. 特に1891年 Peabodyが提唱した脳血管痙攀 説恃長く支持され ${ }^{41}$ ，現在でもその立場をとるすのが皆 無ではない年，しかし，脳動脈瘤破裂のよ5な血管破綻 や强い機械的刺激などの負荷を与えない限り，脳虚血を 生ずるほどの自発的眇血管痘繁忧起こらないと考えられ

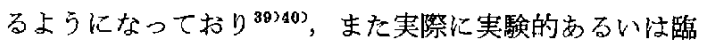
床的に TIA が脳血管痓等で起こることを確認した成績 にそしいこともあり，現在で注脳血管摹縮説に否定的立

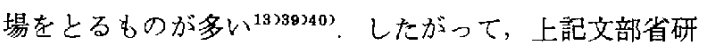
究班の分類に西る反復性局所性畄虚血発作に対寸る(以 わゆる脳血管痤戀）という但書きは汪とんど死文化して いる.

現在一般に容認されている TIA の発症機序の説明と しては，䍁灌流圧の渡動によるとする脳血管不全説と thromboembolicな過程が関与するとする微小塞栓説があ る.

\section{1. 脳血管不全}

1951年 Denny-Brown は8)，それまでいわれていた脳 血管痓憵説を批判し，TIAの発症に一過性の血圧下降か 関与することを強調した。すなわち，内頸動脈や脳動脈 の一部に閉塞・狭窄などの血管病変がある場合, 副血行 などに上りある程度血流が保たれれば無症状に経過する が，かかる例で一過性の血王低下が起こると局所的な脳 虚血と紧症状が出現し，血圧回復とともに症状が莌解す るとしたのである。1953年 Corday らはこの病態を脳血 管不全 cerebrovascular insufficiencyと呼んだが》，これ にショック時の失神まで含めたため，すでに触れたごと く，脂血管不全の概念に混乱を招く罪を犯した，周知の よ5に，脳循環系には強力な自己調節機構があり，灌流 圧の変動に抵抗して血流を一定に維持する機能を有す る.したがって，正常人では血圧の変動がただちに脳血 流量に影響を及ぼすことはない，しかし，先行する血管 病変のため脳循環の自己調節機構に脆弱部があると，軽 
度の血压下降でも局所的な媨虚血を起こす。 Corday が拡大解釈したショック時の意識障害は，脳循環の自己 調節能の正常闇值（平均動脈血圧でほ 活 $60 \mathrm{mmHg}$ ) 以 下に血圧が低下した㻮の譄全体の血流減少であって， Denny-Brown が指摘した病態とは明らかに異なる。 Denny-Brown のいら病態を脳血管不全といらならば， 先行する血管病変のため脳循環の自己調節機構にlocus

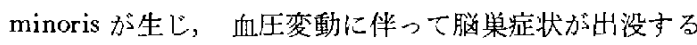
場合に限っで用うべきであると考える，次に，典型的な 自験例を示す。

症例 1 (美原記念病院)：主訴，一過性右片麻痺. 数 年前上り高血圧の既往あり，2力月前加ら右上下肢の脱 力と発語障害の発作を 2 回認めているが，いずれす数 10 分で自然寛解している。寛解時には明らかな神経症状を 認めない，血管写では，左中大脳動脈起始部に著明な狭 窄像が確誌された（Fig. 1 a). 本例注 ${ }^{133} \mathrm{Xe}$ 内頸動脈注 入による局所譄血流（rCBF）の測定中，初回测定 (Fig. $1 b$ ，上段）終了後，平均動脈血圧が 160 から $140 \mathrm{mmHg}$ に下降し，同時に右不全片麻㾴と発語障害加出現した。 $こ の$ 時の $\mathrm{rCBF}$ 仗, 左中大脳動脈領域の一部に著明な低

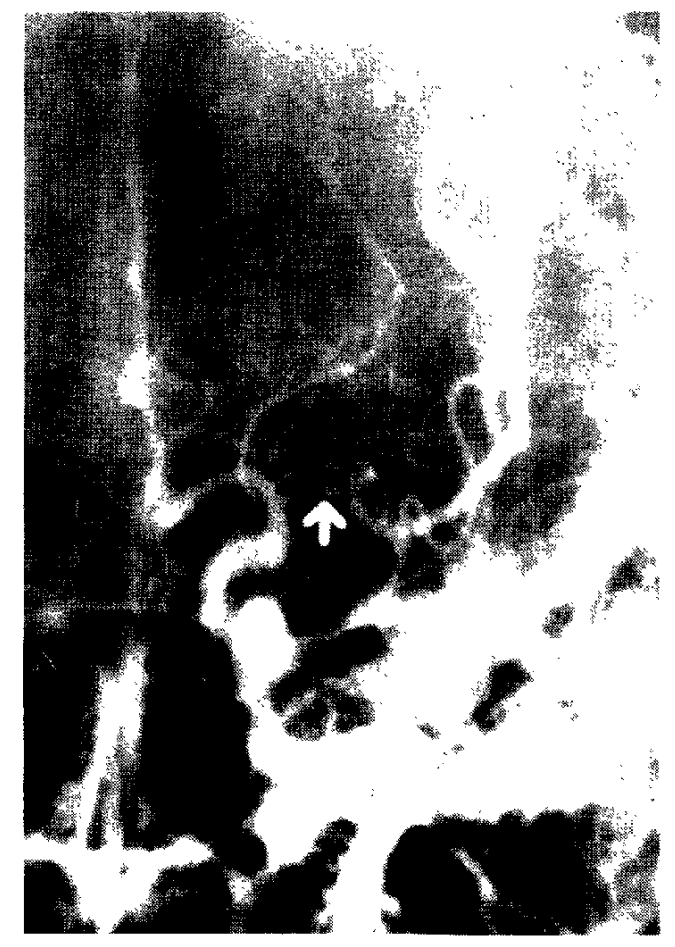

Fig. 1 a Left carotid arteriogram of Case 1. A marked stenotic focus (arrow) was observed in the proximal part of the middle cerebral artery
下がみられた（Fig.1 b下段).約30分後，血压が旧值に 戻るとともに症状が消失した。

かくのごとく，一過性の血圧下降に伴ら TIA が確か に存在している. しかし, Denny-Brown のいらよ5に TIA患者の80\%が腷血管不全によるとするのは過大であ

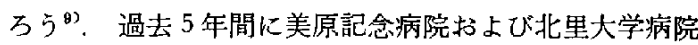
で释験した42例の内頸動脈系 TIA のうち，明らかに檤 血管不全によると思われたものは，症例 1 学含め中大脳 動脈狭窄 2 例, 内頸動脈閉塞とモヤモヤ病の各 1 例の計 4 例しかない. Kendall らは沈3，37例の TIAのらち血 圧下降が発作を誘発したのは1例に過ぎなかったとして いる.

\section{2. 㙐小塞栓}

ナでに1880年 Jackson が一過性左片麻疸患者の原因と して塞栓を想定しており ${ }^{22}$ ，その発想は脳血管痙縉説よ り古い，东た1948年 Pickering TIAの原因として塞栓 重視したが42)，現在定説化している微小塞栓説を唱え

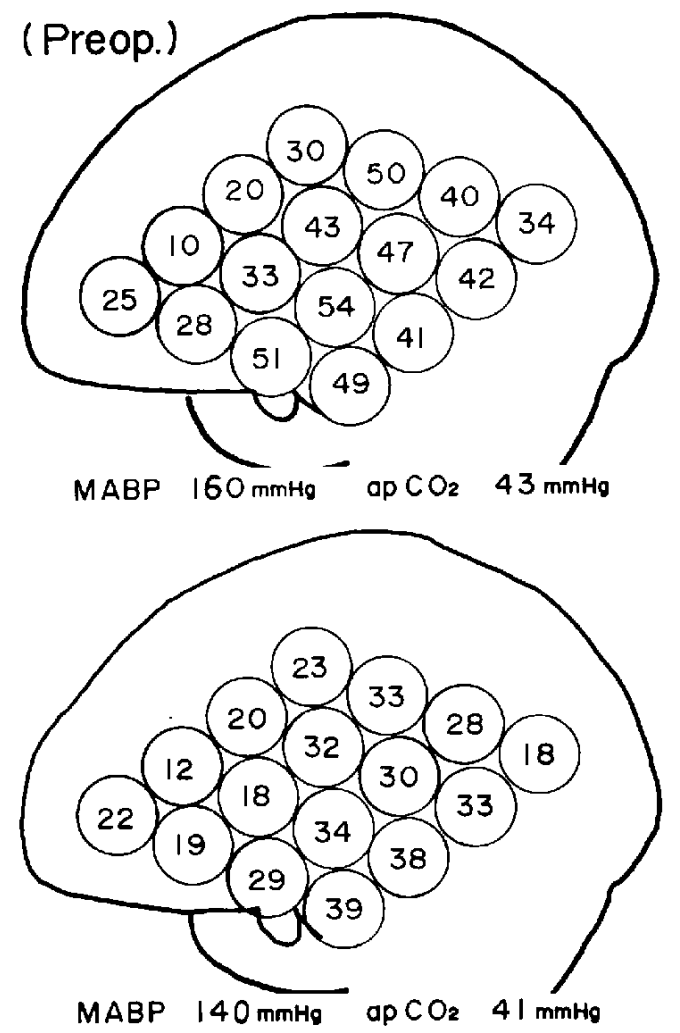

Fig. 1 b Regional cerebral blood flow measurements in Case 1. Reduction of arterial blood pressure (MABP $160 \rightarrow 140 \mathrm{mmHg}$ ) produced decreases of $\mathrm{rCBF}$, especially in the MCA area 
たのは1955年 Millikanらである34)355，彼らは TIA の 出現が必ずしも血圧変動と一致して坊らず，また抗凝血 薬が TIA の発作抑制に有効であることから，本症は主 幹動脈の内膜病変に生した clotが遊㕍して末梢部を閉塞 し，一時脳巣症状を出現させるが，それが細片化して流 れ去ることにより症状が回復するとした，その後, 一過 性失明患者の網膜動脈中を微小塞栓子が移動するのが直 視下に観察され ${ }^{15)}$ ，この塞栓子の本体は血小板血栓を主 体上していることが判明し ${ }^{32}$ ，またかかる例の内钼動脈 アテローム硬化巣の内膜剝離標本に壁在性の血小板 フ イブリン血栓の存在が確認された ${ }^{19}$. このため，当初 Millikan らが clotとした塞栓子は，現在では壁在性の血 小板血栓遊敎片と考えられている，心疾患などに命併す る壁在血栓による脱塞栓では，しばしば閉塞血管の自然 再柾通がみられる，血小板血栓による微小塞栓の場合さ らにその傾问が強いと考えられるが， Sherry olysin の関与を推定している44. これらの事䒠に加え て，頸部動脈に硬化性病変のない心疾患患者でもときに

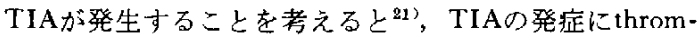
boembolic な機序が関与するものが多いことはほぼ確奏 である。ここで著者らが報告した抗凝血薬が著效を示し たTIA 例在紹介する。

症例 $2^{18)}$ : 68 f, 男性. 主訴. 頻発する一過性左片麻
疩. Fig. 2 に示すごとく，入院 3 日前から 1 日数回，5 １0分持続する然発性の左片麻痺と構音障害の発作をく り返えしていたが，間久期には明らかな神経症状はな い，心は正常大で不整脈なく，心電図にも異常はない。 発作時と宽解時の血圧には明らかな差はない，血管写で は，右内頸動脈起始部に軽度の壁不整があったが，頭蓋 内動脈の明らかな狭䆓・閉塞は諗められなかった。入院 後も频回に発作が出現したが, heparin と sintronに上り prothrombin 時間を $20 \sim 30 \% に$ 維持したところ，発作が 完全に消失した，以後 3 年半の経過観察中，発作の再発 をみていない.

最近では，aspirinなどの血小板凝集阻止剤を使うこと が多いが，それによっても TIA が抑制されることが少 なくない12〉。下はその自験例である。

症例 3 (北里大学病院)：49才，男性，主訴，頻発す

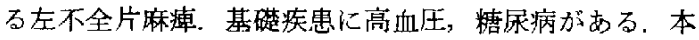
例は，1974年12月加ら1976年 3月までの15力月問に $5 \sim$ 10分間の左不全片麻㾝発作を 20回以上経験していたか， 1976年 4 月加方 aspirin $600 \mathrm{mg}+\operatorname{MDS} 900 \mathrm{mg}$ /日皇投 与したところ，以後完全に発作が消失している，本例の 血管写では，右内頸動脈起始部にアテローム硬化单の潰 癔形成を疑わせる niche があり (Fig. 3，矢印）ここれが 責任病单と推定される.

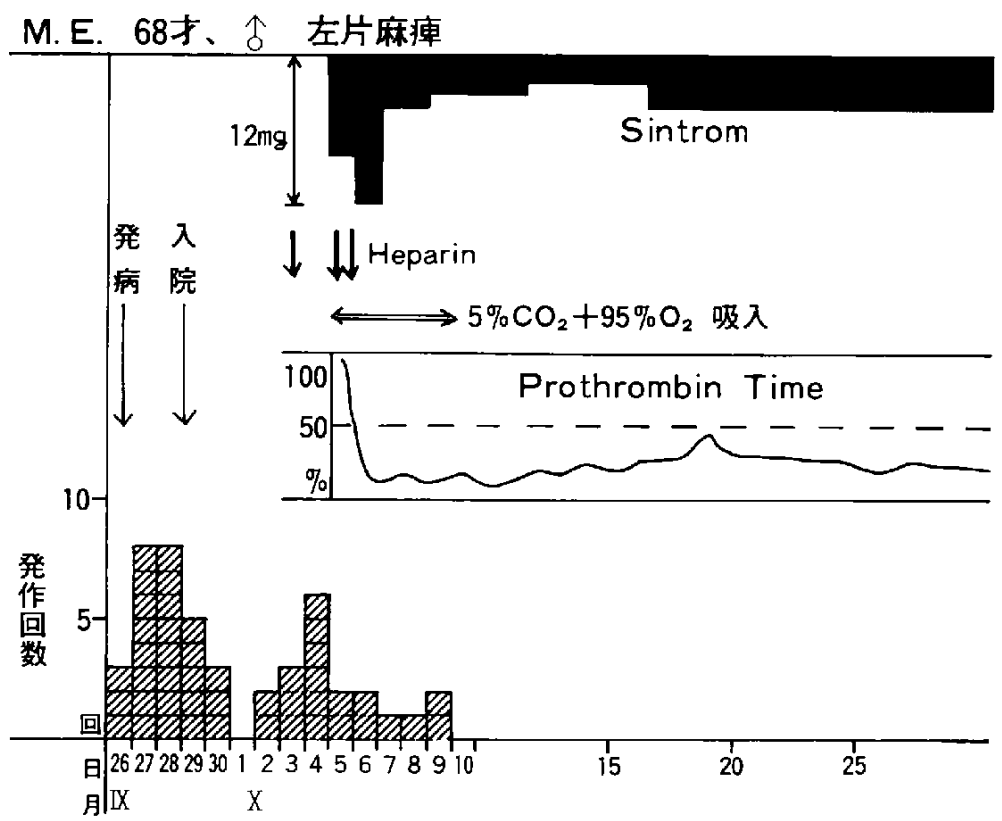

Fig. 2 (Case 2!. Frequent episodes of TIA disappeared after maintaining the prothrombin time below 30 pcrcent. Right carotid arteriography revealed slight irregularities of vascular wall in the proximal part of the rt-internal carotid artery 


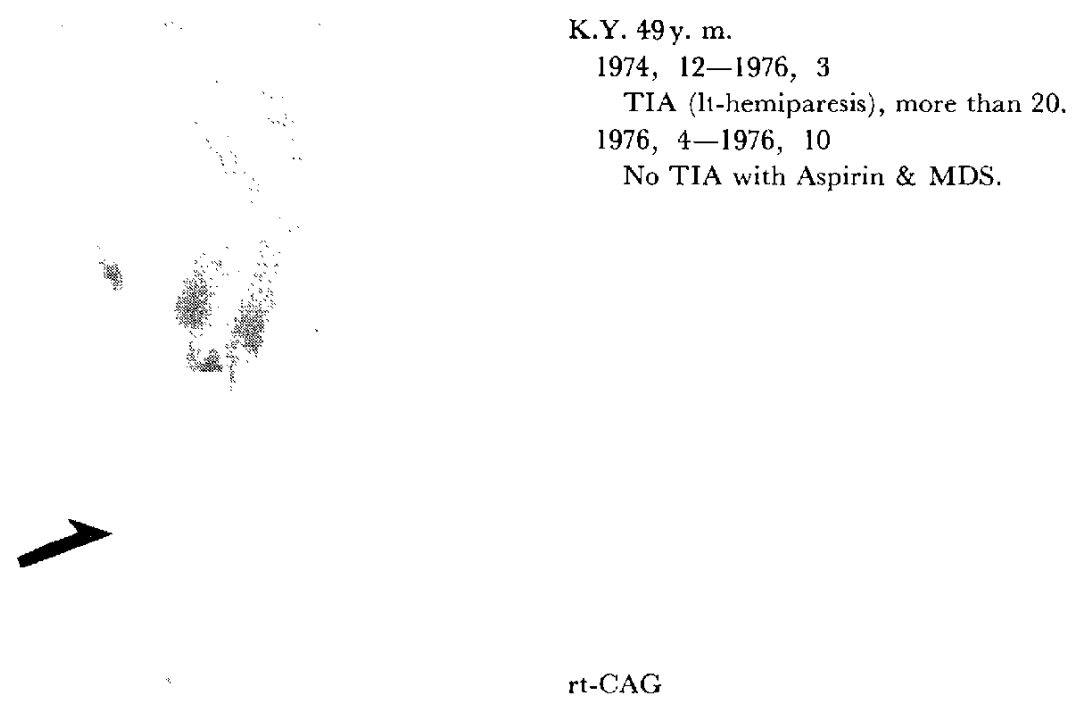

Fig. 3 Atherosclerotic changes and formation of niche in the arteriogram of Case 3

このような血小板血栓を生ずる責任病巣としては， 欧米では顓部動脈のアテローム硬化が重視されている が $^{15 / 90331511)}$ ，我国では頭蓋内動脈の変化が多いといわれ ている ${ }^{23 ?}$ ，過去 5 年間の内顁動脈采 TIA の自験例42例 のうち，心房細動や左心房粘液腫などの心疾患 3 例, お 上ひ脑血管不全を疑われた 4 例を除いた35例の檤血管写 では，13例（37．1\%）がほぼ正常であり，10例(28.6 \%) が主として内頸動脈，8例 $(22.9 \%)$ が中大慆動 脈，4例 $(11.4 \%)$ がその両者に内腔 $30 \%$ 以上の狭蜜や 壁不整などの血管病変を認めた，判定基準に相異がある ことから直ちに他の成績と比較することは困難である が，久保 ${ }^{283}$ の6.5\%，潼田ら ${ }^{47)}$ の $85.7 \%$ 亿比較吉ると頭 蓋内動脈の動脈硬化性変化の発生頻度注少ない，しか し，欧米の報告に比較するとかなり多い，心由来のTIA は全体で7. $1 \%$ (3/42) であった。

主幹動脈または心に壁在血栓を生じらる変化が認めら れる場合は, Millikan Бのい5微小塞拴説を容認しや すいが，頭蓋内動㟲に変化のある場合，下記のごとく， 必ずしる塞栓を起こしたとはいえない例もある。

症例 4 (北里大学病院) : 61才, 男性. 主訴. 反復寸 る右不全片麻疩. 1973年 5 月末加ら1 力月間に5回の右 不全片麻㾝のTIA 癹めたが，MDS $900 \mathrm{mg} /$ 日の投 与開始後完全に発作が消尖し, 以後 3 年間無症状で経過 している。本例の血管写で注，左中大脳動服主幹部に90 $\%$ 以上の狭窄を示す部分があり，この部位が責任病巣と 推定される (Fig. 4)。MDS 投与で発作が消失したこと
から，血小板凝集が発症に関与したことは明らかである が、この部位に血小板血栓を生ずるとただちに内腔開塞 を起こすことも考えられ，そのための TIA も否定はで きない。

一方，血管写上明らかな病変を認めず，なた心疾患も 否定しらる症例で抗凝血薬が発作抑制化奏效した例もあ る。この場合も頭蓋内小動脈に生じた血小板血栓そのも のが TIA の原因となった叮能性を否定できない。した がって, 確加に thromboembolic な過程で TIAが起こる と考えられるが，すべてが塞拴を生じたとする必要もな いと思加る、特に頭蓋内血管病変の多い日本人の場 合，その可能性が高い，

いずれにせよ，TIA患者の70\%以上は抗凝血薬療法で

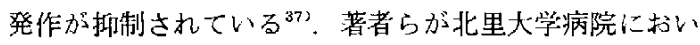
て aspirin などの血小板凝集阻止剂妾使用した 8 例のう ち，無効例注 1 例のみであった。

\section{TIA の成因}

TIAの発症機序は，上記の thromboembolic process に よるものが王倒的に多く，脑血管不全に上ると思われる 典型的な TIA は少ない，成因的にみると，すでに述べ たごとく，両者とむ先行する血管病変があり，そのほと んどが動脈硬化性病変である。しかし，上きにかなり特 哄的な原因疾患による TIA も程験される。

䣆部動脈の血流障害をきたすものの中には频椎の圧迫 によるものや゙， 内頸動脈の kinking や coiling が原因 
M.G. 61 y.m.

TIA (rt-hemiparesis)

$1973,5.28$
6. 4
6. 18
6. 20
6. 27

MDS $900 \mathrm{mg} /$ day start
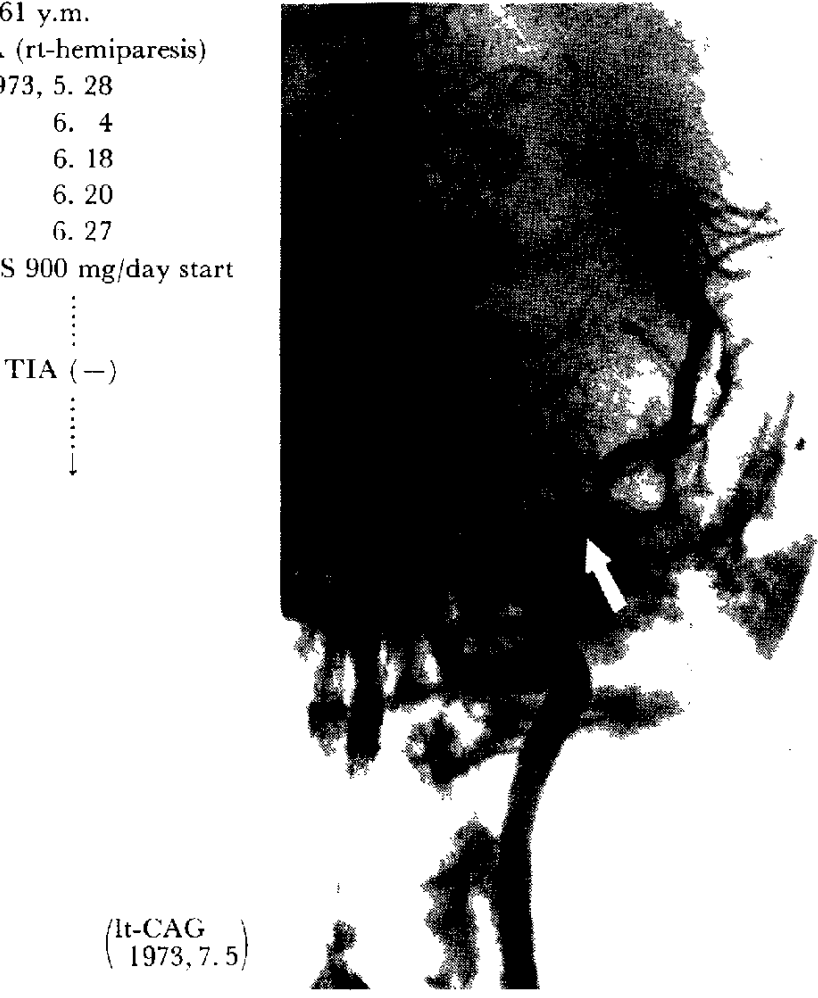

Fig. 4 A marked stenosis of the left middle cercbral artery observed in Case 4

となったものがある每文11. また subclavian stcal syndrome がTIA 様発作を示した例を経駼している行、モ ヤモヤ病の TIA るする。これらはいずれも発症機序上 しては局所的な灌流压低下が考えられ，㮸血管不全の曲 型としらる.

一方, thrombocmbolicな起こり方をするものの中に注 血液性状の変化が原因となるものがある，特に多血症で は血液粘婤度の元進とともに血栓形成傾向が強くなり,

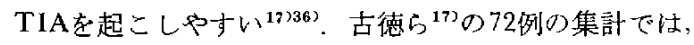
27例に脳血管障害夻併し，うち4例が TIA となって いる.同様に，血小枚増加症でも TIA を起こしやす (28).

特殊な発症機序によるものでは，虚血を伴わずにlIA と同じ症状を呈するものがある。才なわち，Siekertら は著明な鉄欠乏性貧血で TIA 様の発作をみた症例を報 告し，貧血の改善により発作が消失したとしている。一 般に貧血は血液粘䅕度を低下させ，むしろ血流増加性に 作用する.したがって，この場合は虚血よりも酸素供給 量の低下が症状発現に関与したものと考えられる。これ に類するものでは，低血糖で同様症状をみたといら報告

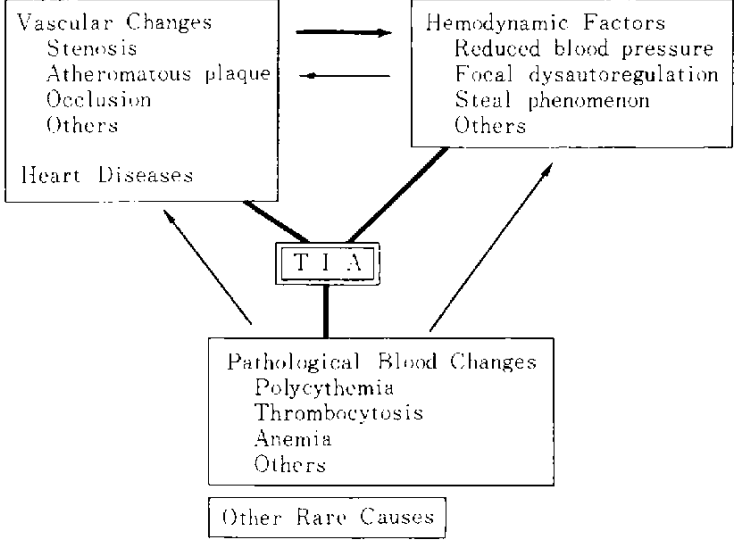

Fig. 5 Various pathogenic factors of TIA

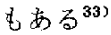

以上述べた TIA の成因を一括すると，执よを Fig. 5 のごとくまとめることができる。これらの成因の組合 せに上り種々の形で TIA が起こりうるが，多くの場合 その発症機序を血栓一塞栓機転加腷血管不全に帰寸るこ 
とができる。

\section{IV 発症機序からみた血行再建術の適応}

TIAの発作が初回のみといらものが欧米の報告ではか なりあるが $\left(16 \sim 23 \%{ }^{3303}\right)$ ，本症の特徴の一つ海発作の 反復であり，しかも这梗塞一移行する危険が大きく，特 に我国ではこの傾向が強い ${ }^{38523}$ ，したがって，TIAの治 漅汇単に発作の抑制のみならず，将来起こりうる腷梗塞 の䂆方といら立場で捉える必要がある。現在に扝ける TIAO内科的治療の主流は，血液の凝固能抑制に上る発

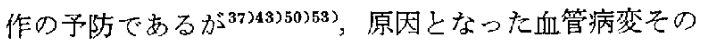
るのの修復ではない。このた，TIAの原因潦法として 血行再建術がかなり以前加ら試双られている

TIA に対寸る血行再建術としては，内膜除去術と bypass 造成術とがあげられる。

内膜除去術は米国においてすでにかなりの害績があ り，TIAの発作抑制に対して抗凝血薬上ほぼ同様の効果

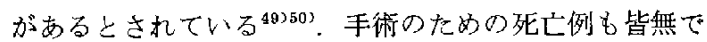
はないが(多くは1〜3\%) , 米国の Joint study of extracranial arterial occlusion の42力月の追跡調查では, 外科的処置と保存的㞠法已の間に死亡率の差学認めてい ない"，我国で汢，まだ広く普及しているとはいえない が，外科的好置が原因療法であるこ上を考えると，頙部 内頸動脈に狭窄やアテローム硬化单を認めた場合は，加 なり積極的に内膜除去術を試みるべきであると考える。

Yasargil $ら^{543}$ の報告以来，我国でもSTA-MCA 吻合 を主しする脑血管の bypass造成術が最近試みられつつあ るが2゙，その評価はまだでていない，病態生理学的にみ

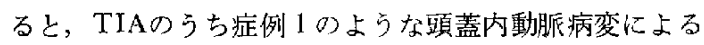
脑血管不全例や，内頸動脈閉塞，モヤモヤ病などによる 場合は十分その適応が洘えられる 数が少なく，今後保存的療法との遠隔成績の対比検討が 必要であると思わ扎。$$
V \text { ま } め
$$

以上，TIAの発症機序と成因について概説し，その多 様性紹介した。

TIA沬ひとつの症侯群であって，その成因および発症 機序は一律ではないが，類型化すると次のごとくであ 乃.

1. 頭蓋内外の血管に動脈硬化を主とした先行する病 変また㤌心疾患があり，thromboembolic な過程に上っ て発症するるの（いわゆる微小塞栓によるもの）.

2. 先行す豆頭蓋内外の血管病変のため, 脳循環自己 調節機構に locus minoris を生じ，血圧変動により症状
が出没するもの（脳血管不全によるもの）。

3. 血液凝固性亢進が主因となるもの.

4. その他の特硃な病㷫によるもの.

これらの類型のうら，特殊なもの孝除けば，血行再建 術の適応として钼部動脈の病変に基づく thromboembolic な TIA では内膜除去術が考えられ，STA-MCA 吻 合術の場合注腷血管不全によるものが対象疾患となり ると思われる。

本論文は，第35回日本檤神経外科学会総会の虚血性脑 病変に対するSTA-MCA 吻合術に関するシンポジん の発表要旨をまとめたすのである，最後に，本発表の機 会を与えて頂いた川淵純一教授ならびに亀山正邦教授に 滐勆致し亡す。

\section{文献}

1) 相沢豊三：腦卒中の概念，相沢豊三編：医 学 シンポジウム21集, 脳卒中, 診断と治療社, 東 京, $1967, \mathrm{p} 1$

2) Austin, G., Laffin, D. \& Hayward, W.: Physiologic factors in the selection of patients for superficial temporal artery-to-middle cerebral artery anastomosis. Surgery 75: 861-868, 1974

3) Baker, R. N., Ramseyer, J. C. \& Schwartz, W. S.: Prognosis in patients with transient cerebral ischemic attacks. Neurology 18: 11571165,1968

4) Bauer, R. B., Sheehan, S. \& Meyer, J. S.: Arteriographic study of cerebrovascular diseases. II Cerebral symptoms due to kinking, tortuosity, and compression of carotid and vertebral arteries in the neck. Arch Neurol 4: 119-131, 1961

5) Bauer, R. B., Meyer, J. S. Fields, W. S. et al. : Joint study of extracranial arterial occlusion III: Progress report of controlled study of long-term survival in patients with and without operation. JAMA 208: 509-518, 1969

6) Browne, T. R. III \& Poskanzer, D. C.: Treatment of stroke (First of two part). New Engl J Med 281 : 594-602, 1969

7) Corday, E., Rothenberg, S. F. \& Rutman, T. J.: Cerebral vascular insufficiency. An explanation of some types of localized cerebral encephalopathy. Arch Neurol Psychiatr 69: 551570,1953

8) DeNNy-BRown, D.: The treatment of recurrent cerebrovascular symptoms and the question of "vasospasm." Med Clin North Am 35: 14571474,1951

9) DeNnY-BRown, D.: Recurrent cerebrovascular episodes. Arch Neurol 2: 194-210, 1960 
10) Derrick, J. R. \& Smith, T.: Carotid kinking as a cause of cerebral insufficiency. Circulation 25: 849-853, 1962

11) Desai, B. \& Toole, J. F.: Kinks, coils, and carotids. A review. Stroke 6: 649-653, 1975

12) Dyken, M. L., Kolar, O. J. \& Jones, F. H.: Differences in the occurrence of carotid transient ischemic attacks associated with antiplatelet aggregation therapy. Stroke 4: 732-736, 1973

13）海老原進一郎：一過性脳虚血. 田㥓義昭編： 成人病診療講座 3, 檤卒中, 金原出版, 東京, 1975, p 203

14) Fisher, C. M.: Occlusion of the carotid artery: Further experiences. Arch Neurol Psychiatr 72: $187-204,1954$

15) Fischer, C. M.: Observations of the fundus oculi in transient monocular blindness. Neurology 9: 333-347, 1959

16) Frank, G.: Comparison of anticoagulation and surgical treatment of TIA. A review and consolidation of recent natural history and treatment study. Stroke 2: 369-377, 1971

17）古徳利光，川上倖司，丹野慶紀：真性多血症 と脳血管障害一症例報告と本邦における統計的 観察。臨床神経 10：585-592，1970

18）五島䧸一郎，田崎義昭，斉藤佳雄，沢田 徹 : 抗凝血葲加奏効せる recurrent transient focal cerebral ischemia $O 1$ 例. 臨床神経 3:179-183, 1963

19) Gunnisg, A. J., Pigkering, G. W. \& RobbSmith, A. H. T. et al.: Mural thrombosis of the internal carotid artery and subsequent embolism. $Q J$ Med 33: 155-195, 1964

20) Heymann, A. (chairman) et al.: Report of the joint committe for stroke facilities. XI. Transient focal ccrebral ischemia: Epidemiological and clinical aspects. Stroke 5: 276-287, 1974

21) Hutchinson, E. C. \& Stock, J. P. P. P. Paroxysmal cerebral ischemia in rheumatic heart diseases. Lancet $I I: 653-656,1963$

22) JACkson, J. H.: On a case of temporary left hemiplegia. Brain 3: 433-451, 1880

23) Kameyama, M. \& Okinaka, S.: Collateral circulation of the brain with special reference to atherosclerosis of the major cervical and cercbral arteries. Neurology 13: 279-288, 1963

24) Karasawa, J., Kikuchi, H., Furuse, S. et al. A surgical treatment of "Moyamoya" disease. "Encephalo-Myo Synangiosis." Neurol Med Chir 17 (Part I) : 30-37, 1977

25）勝訃司馬之助：脳血管障害の疫学、冲中 重 雄 編：内科シリーズ 1, 脳卒中のすヘて, 南江堂, 東京, $1971, \mathrm{p} 45$

26) Kendall, R. E. \& Marshall, J.: Role of hypotension in the genesis of transient focal cerebral ischemic attack. Br Med $J$ 10:344-348, 1963

27) 㐘地晴彦: 中大譄動脈閉塞の外科. 大根田䓋 寿他編：脳卒中 III，脳硬塞，にゅ一万ん社，東 京, $1976, \mathrm{p} 71$

28）久保浩一：一過性脳虚血発作一脳動脈写に上 る検討一。内科22：969-978，1968

29) Levine, J. \& Swansan, P. D.: Idiopathic thrombocytosis. A treatable cause of transient ischemic attacks. Neurology 18: 711-718, 1968

30) Marshall, J.: The natural history of transient ischemic cerebro-vascular attacks. $Q J \mathrm{Med} 3$ 309-324, 1964

31) Martin, H. J., Whisnant, J. P. \& Sayre G. P.: Occlusive vascular disease in the extracranial cerebral circulation. Arch Neurol 3: $530-538,1960$

32) MaBrien, D. J., Bradley, R. D. \& Ashton, $N$.: The nature of retinal emboli in stenosis of the internal carotid artery. Lancet I: 697-699, 1963

33) Meyer, J. S. \& Portnoy, H. D.: Localized cerebral hypoglycemia simulating stroke. Neurology 8: 601-614, 1958

34) Millikan, C. H., Siekert, R. G. \& Shick, R. M.: Studics in cerebrovascular diseases. III The use of anticoagulant drugs in the treatment of thrombosis within the basilar arterial system. Mayo Clin Proc 30: 116-126, 1955

35) Millikan, C. H., Srekert, R. G., \& Shick, R. M.: Studies in cerebrovascular diseases $V$ : The use of anticoagulant drugs in the treatment of intermittent insufficiency of the internal carotid arterial system. Mayo Clin Proc 30:578586,1955

36) Milizan, C. H., Siekert, R. G. \& Whisnant, J. P.: Intermittent carotid and vertebral-basilar insufficiency associated with polycythemia. Neurology 10: 188-196, 1960

37) Millikan, C. H.: Reassesment of anticoagulant thcrapy in various types of occlusive cerebrovascular disease. Stroke 2: 201-208, 1971

38）西丸雄也，尾前照雄，勝木司馬之助：反復性 局所性脳虚血発作の追跡調査の試み。日老医詰 $8: 293-296,1971$

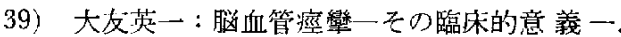
田崎義昭編：成人病診療講座 3 , 脳卒中, 金原 出版, 東京, $1975, \mathrm{p} 291$

40) Paulson, O. B.: Cerebral apoplexy (Stroke) Pathogenesis, pathophysiology and therapy as illustrated by regional blood flow measurements in the brain. Stroke 2: 327-360, 1971

41) Peabody, G. L.: Relations between arterial and visceral changes. Trans Assoc Am Physicians $6: 154-175,1891$

42) Pickering, G, W, : Transient cerebral paralysis 
in hypertension and in cerebral embolism. JAMA 137: 423-430, 1948

43) 沢田 微: Subclavian steal syndrome 一自験 例上文献的考察一. Geriatrics Med 12:549-555, 1974

44) Sherry, S.: Incipient strokes: Dynamics of thrombosis. p 61, In, Millikan, C. H. et al. (eds) Cerebral Vascular Diseases, III Conference: Grune \& Stratton, New York, 1961

45) Siekert, R. G., Whisnant, J. P. \& Millikan, C. H.: Anemia and intermittent focal cerebral arterial insufficiency. Arch Neurol 3: 386-390, 1960

46）鈴木二郎：一過性脑虚血発作の機序. 後藤文 男, 田㱦義昭編 : 専門医にきく腷血管障害 $の$ 臨 床, 中外医学社, 東京, $1973, \mathrm{p} 180$

47）滝田杏児，越広，中谷敏太郎：一過性脳 虚血発作一特に反復性局所性脳虚血発作につい て一, 最新医学25 : 1245-1249，1970

48）田崎義昭, 沢田 徹: 一過性䏼虚血発作一成 因拉よび治療一，日本臨床34：64-71，1976

49) Thompson, J. E., Austin, D. J. \& Patman,
R. D.: Carotid endarterectomy for cerebrovascular insufficiency: Long-term results in 592 patients up to thirteen years. Ann Surg 172: 663679, 1970

50) Toole, J. F. (chairman) et al.: Report of the joint committee for stroke facilities. VII. Medical and surgical management of stroke. Stroke 4: $270-320,1973$

51) Toole, J. F., Janeway, R., Chor, K. et al.: Transient ischemic attacks due to atherosclerosis. A prospective study of 160 patients. Arch Neurol 32: 5-12, 1975

52）冢越 広：一過性媨虚血発作. 相沢豊三 編 : 医学シンポジウム21集，診療と治療社，東京， 1967, p 215

53) Whisnant, J. P. (chairman) et al.: Report of the joint committee for stroke facilities. V. Clinical prevention of stroke. Stroke 3: 804-825, 1972

54) Yasargil, M. G., Krayenbuhl, H. A. \& JACOBSON, J. M.: Microneurosurgical arterial reconstruction. Surgery 67: 221-233, 1970 